\title{
One of the less horrible of the many dystopian futures visited by the Time Traveller
}

\section{Watch and wait. By Rahul Kanakia}

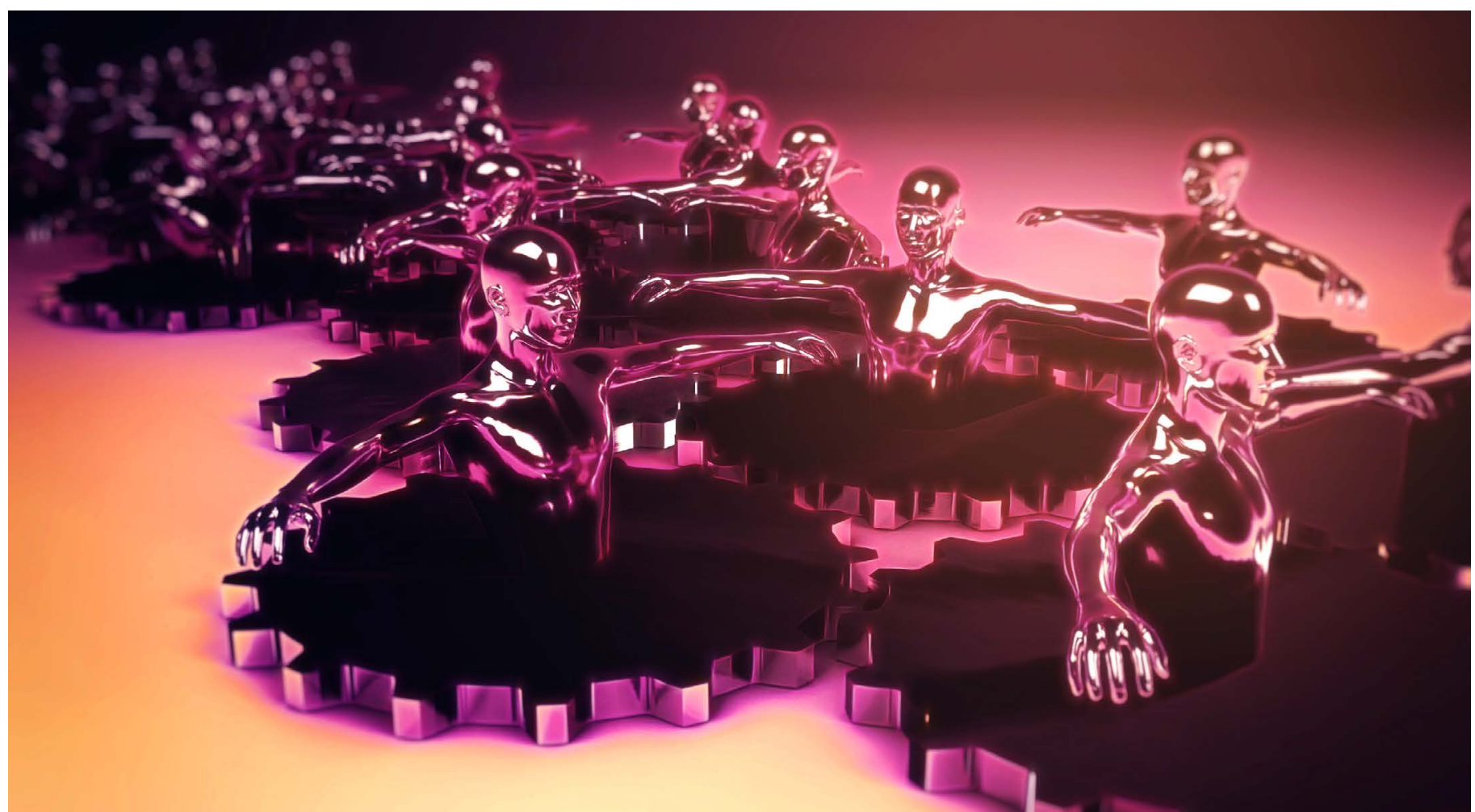

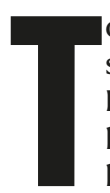
o the casual eye, this city didn't show signs of excessive order or disorder. It was neither monocultural nor recklessly cosmopolitan. The brick townhomes and neoclassical government buildings were leavened with a healthy variety of styles, including some that the Time Traveller recognized from his own era. Human beings were organized, as was frequently the case, into nuclear family units, living within individually owned apartments and houses. But they did not seem to practise a currency economy, and this led to a number of confusing exchanges between the Time Traveller and his tour guide: a stolid, unblinking individual, squat in appearance, ashen in complexion, and with some characteristics suggestive of the female sex.
"Where does food come from?"

"It grows," said the Unblinking Guide.

"Who grows it?"

"A mixture of complex multinational businesses and smaller, individually owned farms."

"So you have private enterprise."

"And public enterprises."

"Well, to cut a long story short," the Time Traveller said, "I've found, when looking for a society's tragic flaw, that it's best to search for the underclasses. What about the poor? The ill-educated? Those who lack capital?"

“We don't have any poor. Those who want capital are given it. Those who want education can enrol in school."

“But what about those who don't want to work? Admittedly, I don't love that way of speaking - it's always more complicated than a question of laziness or industriousness -"

“People don't need to work."

"Ah-hah, then where does their food come from? Their shelter? Their -"

“They produce it."

"But ... we were talking about those who don't want to work ..."

The Unblinking Guide shrugged and put the velocipede into motion. Although the vehicle had a steering wheel, the Guide didn't actively drive it. The vehicle drove itself, pulling into traffic and neatly matching the speed of other velocipedes. However, the Guide still refused to speak or even acknowledge the Time Traveller's presence while the vehicle was moving.

Taciturnity was a ubiquitous feature of this 


\section{Futures}

era. Wherever he went, the Time Traveller found silence. Clerks sitting unblinking and still in front of computer monitors where words appeared on their own. Workmen and work-women, garbed in hard hats and denim, standing by and watching machines construct housing on an empty plot. Children holding little gadget boxes while toy star-fighters whooped and swarmed all around them.

"What are the kids doing? Are they controlling the game with their minds?"

“No," the Guide said. "With their hands. Are you unfamiliar with electronic gaming?"

"But their hands aren't moving."

"Well, the computer does most of the work."

Everywhere, this society carried the same sleep-walking quality. Machines did the work, and human beings watched. The Time Traveller was at a loss to understand. If the systems were automatic, the human beings ought to walk away and disport themselves in beautiful pleasure gardens while the machines toiled on their behalf. Of course, that would inevitably lead to the disintegration of the human race in a haze of meaningless hedonism, but the truth about the future was that it almost always led to the disintegration of the human race in one way or another.

The Time Traveller's breakthrough came during a long drive across a baking desert highway, when he saw the Unblinking Guide's hand touch the steering wheel ever-so-briefly.

"Why did you do that? What was that adjustment?" the Time Traveller asked.
"An animal in the road. I avoided a collision."

"So you truly are on some level controlling this machine?"

"Of course."

With a hypothesis to focus his questioning, the Time Traveller surmised that within this society, artificial intelligence had reached a high, but still sub-human level. Although machinery was all-but-autonomous, a human brain was still needed to assess and correct any errors. Active intervention was rare, but all systems required constant monitoring, because any potential errors could be catastrophic. Generations of natural and societal selection had then run their course. Any human beings incapable of giving their continuous, undivided attention to a machine process had found themselves unable to work. Or at least unable to produce the resources necessary for survival. The result was an unimaginative, unthinking society where the human beings were simply another $\operatorname{cog}$ in the machine.

Another future, another technological scenario run amok. The Time Traveller went back to his home era and wrote up a short account of his visit to AD 2203.

In the future he'd left behind, a group of excavating machines eventually found a copy of the Time Traveller's document and brought it to the attention of the Unblinking Guide.

The Guide immediately intuited several errors of understanding in the Time Traveller's writing, but the Guide also understood that to someone with the Traveller's fragmentary consciousness it would be quite difficult to perceive the beauty of modern society. The Guide excoriated herself for her failure to make the Traveller understand the ecstasy of watching and waiting and overseeing a machine - how it was almost painful to be tossed into the real-time gabble of communication and conversation - and how their society, far from being an example of humankind's doom, was, rather, its apotheosis.

It didn't feel great to have made such a gargantuan botch of the job for which she'd trained her whole life. And yet she had no choice but to forgive herself and resume her post in the hub of sensor stations. Through the use of neural networks, they had become better and better at preventing temporal anomalies, but on occasion a traveller still got through and wreaked havoc on their heuristics.

It was too soon to know the result of the Time Traveller's negative report. Perhaps his report would be ignored. Perhaps his people wouldn't understand it. Or perhaps the mechanics of time travel - still largely unknown would mean that the report was doomed to ineffectiveness. Perhaps the Unblinking Guide's mistake wouldn't result in calamity and the loss of everything she held dear. Regardless, all she could do was wait and watch.

Rahul Kanakia is a writer based in San Francisco. This is his sixth story in Nature Futures. 